\title{
POLITENESS: CULTURAL DIMENSIONS OF LINGUISTIC CHOICE
}

\author{
Fitriah $^{1}$, Didin Nuruddin Hidayat ${ }^{2}$ \\ ${ }^{1}$ UIN Sunan Ampel Surabaya, Indonesia \\ ${ }^{2}$ Syarif Hidayatullah State Islamic University of Jakarta, Indonesia \\ (fitriahasad@yahoo.com)
}

Received: $15^{\text {th }}$ March 2018; Revised: $25^{\text {th }}$ May 2018; Accepted: $28^{\text {th }}$ June 2018

\begin{abstract}
Language has a social function to make connection between human beings. Without language, people seem to be impossible to interact with others in their daily communication. In order to sustain the communication well, speakers should be able to choose strategies to have polite conversation. Often politeness strategies are affected by cultural convention, which is based on community's social values. However, every society operates a normative notion of their own politeness, which is not the same for all interlocutors, situations and cultures. In Javanese norm, for instance, the linguistic choice is often influenced by the addressee's age, status, position, relationship, social constraints and gender. This essay will first summarize and comment on some of the salient aspects in Coulmas' article entitled 'Politeness: cultural dimension of linguistic choice', part of his book chapters in 'Sociolinguistics: The study of speakers' choices' (2013). As an English teacher, we should be aware of this difference so that we could introduce the politeness strategies in the target culture to the students.
\end{abstract}

Key Words: politeness strategies; linguistic choice; communication

\section{ABSTRAK}

Bahasa memiliki fungsi sosial dalam menjaga hubungan dengan sesama individu. Tanpa bahasa, seseorang tidak akan mampu berinteraksi dengan orang lain dalam komunikasi sehari-hari. Untuk mempertahankan komunikasi dengan baik, pembicara harus dapat memilih strategi yang tepat dalam melakukan percakapan yang sopan. Seringkali norma-norma kesopanan yang ada dipengaruhi oleh konvensi budaya, yang didasarkan dari nilai-nilai social kemasyarakatan. Namun, setiap kelompok masyarakat memiliki nilai kesopanan tersendiri yang didasarkan dari norma kesopanan yang mereka percayai, dan norma kesopanan tersebut tidak sama bagi semua lawan bicara, situasi dan budaya. Dalam norma Jawa, misalnya, pemilihan linguistik atau kata sering dipengaruhi oleh usia, status, posisi, hubungan, pertimbangan sosial dan gender si penerima. Artikel ini akan mengidentifikasi dan mengomentari beberapa aspek yang penting dari tulisannya Coulmas yang berjudul 'Kesopanan: dimensi budaya pilihan linguistik', bagian dari bab dari bukunya Coulmas yang berjudul: 'Sosiolinguistik: Studi tentang pilihan pembicara' (2013). Sebagai guru bahasa Inggris, kita harus menyadari perbedaan penggunaaan kata atau pilihan linguistic sehingga kita bisa memperkenalkan strategi kesopanan dalam budaya tertentu kepada siswa.

Kata Kunci: strategi kesopanan, pilihan linguistik, komunikasi

How to Cite: Fitrah., Hidayat. D. N. (2018). Politeness: Cultural Dimensions of Linguistic Choice. IJEE (Indonesian Journal of English Education), 5(1), 26-34. doi:10.15408/ijee.v5i1. 


\section{INTRODUCTION}

People can express politeness in a number of ways when they interact with each other; the addressee's age, status, position, relationship, social constraints, gender, and so on. In some occasions, those variables of personal background even could influence the linguistic choices and attitudes in conversation. For example, when younger people talk to the older ones, it will be different when they talk to their peers, either in the way they communicate or in the way they behave. It has been common thing that people in the society would engage in that behavior as "to ensure that everyone feels affirmed in a social interaction" (Foley, 1997, p. 270). Given the importance of politeness strategies in the society, this essay will summarize and analyze some of the salient aspects in Florian Coulmas' chapter entitled 'Politeness: Cultural dimension of linguistic choice'. The article is part of the book chapters in 'Sociolinguistics: the study of speakers' choices' (Coulmas, 2013).

In this chapter, Coulmas (2013) defined the term politeness as based on politeness theory as well as cultural conventions. In a theoretical description, the notion of politeness should be culturally neutral and suitable for politeness differentiation.
Coulmas (2013) further stated that "[politeness] is a non-normative theoretical construct designed to compare various standards used in different societies for the assessment of speech behavior" (p. 85). A cultural convention of politeness refers to judgment of people's speech behaviour on the basis of the community's social values. It seems that a cultural convention originates from a particular sociocultural system, so understanding this notion is a prerequisite to behaving competently in that community. However, any theoretical notion of politeness has to recognize the fact that every society operates a normative notion of their own politeness, which is not the same for all interlocutors, situations and cultures.

Some researchers offer a general approach to politeness, for example, Brown and Levinson (1987) proposed the influential model of politeness, which focuses on rationality and face. Face in Brown and Levinson's terminology, has a positive and a negative aspect. Positive face is the desire to be accepted or liked by others, and negative face is the need to be independent and not be imposed on by others. Earlier before the 'two faces' models, Leech (1983) also offered four different categories according to the inherent functions of communication acts: a) the convivial function of politeness, 
when illocutionary and social communication aim coincide, as in when interactants are greeting, offering, inviting, etc.; b) the collaborative function, where the illocutionary and the social aim are independent of one another, when speakers declare, assert, report, announce, etc.;; c) the competitive function of politeness, where the illocutionary goal competes with the social goal and speakers, order, ask, demand, beg, etc., and; d) the conflicting function, entails a conflict between the illocutionary and the social goal and occurs when speakers threaten, accuse and, in general, express negative feelings and reactions. Moreover, one model after Brown and Levinson's (1987) model was the Fraser's (1990, cited in Kedveš, 2013) perspective on politeness, namely; a) the social-norm view, which sees politeness as socially appropriate behavior, pleasant towards others, b) the conversational-contract view, where politeness is seen within the frames of conversational contract between the interlocutors and suggests its dependency on correct context interpretation; c) the conversationalmaxim view, which is relevant to Grice's (1975) cooperative principles which assume cooperation between the interlocutors, and; d) the face-saving view, which sees politeness as a linguistic behavior with the objective of preserving and/or enhancing one's face.

Coulmas (2013) pointed out that balancing these desires while considering every speaker's positive and negative needs is not easy. This is the art of politeness. He said that "[politeness is] the art of not committing face-threatening acts and protecting oneself again such acts" (p. 86). It is a complex art because every society is built on inequality. Again, speech expressions vary along a politeness scale, and speakers can be more or less polite. This concern is influenced by the common dimensions of sex, age, class, power and wealth of the addressee. For example, 'you may go outside now' is polite when offering an opportunity to a child, but inappropriate when used for someone who is in the position of authority over the speaker. In this case, it is not the term itself that is or is not polite, yet its selection in a given situation.

$\mathrm{He}$ also noted that the interrelationship between speaker politeness and expression politeness is not the same for all languages and speech communities. Some language have richer lexical and grammatical encoding of politeness than others; for example, Korean encodes social relations by means of distinctly different speech levels which mark the 
different degrees of formality, distance and deference the speaker shows to the addressee. Therefore, it will be hard for speakers to be polite if they are not able to bring together the linguistic means and the social norms of appropriate conduct in a particular context.

\section{ASPECTS OF POLITENESS}

Before commenting on some particular aspects of Coulmas' article, we would like to state the reasons for choosing this article. Firstly, our background is Indonesian and in that culture, hierarchy of the language as Coulmas (2013) illustrations is quite similar with Korean. In comparison, English seems to be more egalitarian. Secondly, since politeness strategies are important element for sustaining communication in our culture, it will be very useful for me as a teacher of English to be aware of this difference so that we could introduce politeness strategies in the target culture to our students. As Spradley (1980) stated, language classroom should become an extension of culture learning process. Therefore, students should understand the culture itself in three fundamental aspects that has been proposed by Spradley (1980); what people do (culture behavior); what people know (cultural knowledge); what things people make and use (cultural artifacts).
Thirdly, politeness strategies are also important due to its scope in the society. As Indonesia has so many different cultures which may also share different ways of politeness strategies, this topic would also be beneficial to be included in the classroom, so that students could see intercultural differences in humans' life or what Kramsch (1998) named as 'Sphere of Interculturality' where people could learn from how target culture and students' culture are contrasted. In that case, this chapter could be beneficial for Indonesian context as it reflects how politeness strategies could be different depending on each context.

For non-native speakers to perceive and teach politeness in English seems hard because politeness level in English are only subtly different from one another. For example, in a study by Rinnert and Kobayashi (1999), polite forms are used by Japanese speakers more frequently than by native English speakers. However, does that mean English speakers are impolite? The answer should be a 'no' as the degree of politeness itself might be different. Taking another example, in English there is only one pronominal form of address 'you' for all interlocutors. Therefore, the speakers do not have choices for differentiating the degrees of formality and informality, respect and intimacy. Hence, it can be hard to 
identify differences between speakers in terms of distribution of wealth, power, respect, intimacy and social distance in English-speaking societies. However, in the Indonesian culture, the choices of address terms are richer and often determined by family relationship, social relationship, age, gender and status between speakers and addressees. In Javanese culture, for instance, there are three ways to say 'you' i.e. awakmu, sampeyan and panjenengan. Awakmu is used when we speak with friends or younger people, sampeyan is used between two people of the same age who do not know each other or people to address older siblings, and panjenengan is used to address older people or those who have higher status than the speaker. Another example, Sundanese culture also has different ways only to express 'you'. When Sundanese people talk to someone they really respect, they will use anjeun as to reflect higher social status or formality of situation. It will also be different when they talk to peers or younger people as they will use maneh to reflect casualty of situation and equal social status such as friendship and senior to junior. Lastly, Sundanese will also use different word like siya as to express the impoliteness and hatred to other people. Those words are definitely important to see how the status of the interlocutors or how people see us in such conversation. The use of different forms of address is applied to express, formality, informality, intimacy and respect. The society values these rules governing politeness, and as a member of a social group we have to obey these rules to be considered polite. Kramsch (1998) said that language is a system of signs that is seen as a cultural value. Avoiding the use of its signs may be perceived as a rejection of the social group and their culture. This is due to the function of politeness itself as to maintain social relationship, so that people are required to act appropriately in specific situation. Meier (1995) also supported that being appropriate in a specific society is a key success of a person to maintain social relationships, politeness. Depending on the culture, however, politeness is indicated in different ways and perceived with different meanings. Meier (1995) stated that "every society has some sort of norms for appropriate behavior, although these norms will vary" ( $p$. 388).

Coulmas (2013) pointed that politeness is identified as cultural conventions based on the community's social values, which seems true in the case of Javanese. What is inappropriate according to the society's judgment will be regarded as impolite. Most politeness expressions in Javanese are 
from social values. The words themselves (e.g. awakmu, sampeyan and panjenengan) do not express rudeness but will be labeled impolite if they are applied improperly. For example, if we use 'awakmu' to an elder, that elder will be offended and think that we do not know how to behave politely. Fraser and Nolen, cited in Watts, Ide and Ehlich (1992), suggested that politeness is the result of a conversational contract by the participant in an effort to maintain socio-communicative interaction, which is free of conflict. In Indonesian context, for instance, Aziz (2000, as cited in Chojimah, 2015) mentioned four values in the Principle of Mutual Consideration, namely a) Harm and Favor Potential, which reminds us to be careful in uttering expressions since they are potentially either to harm or favor others; b) Shared-feeling Principle, which reminds us that our addressee has the same feeling as we do; c) Prima Facie Principle, which stresses the importance of impression in the first sight since it is the point at which our addressee evaluates our politeness manner, and; d) Continuity Principle, which suggests that the continuity of our communication is dependent on the present communication.

This article does not say much about the linguistic choices used in English but gives more examples of politeness levels in other languages. For example, the writer states that the statement 'you may go out' is inappropriate when used towards a person who has authority over the speaker, but gives no example of way to express the same thing. For non-native English speaker, this would be confusing and may cause misunderstanding. This should be justifiable because it seems important for us as non-native speakers to see how exactly native speakers do it in their culture. In other words, we understand that different culture may share different ways to express it, but in this case, non-native readers may need some explicit examples to gain better understanding about that topic.

Coulmas (2013) mentioned that there is a correlation between indirectness and politeness. Indirectness can be used as a technique of maintaining face and conflict avoidance. For example, a request in the form of an interrogative sentence (could you have this done by three o'clock) is more polite than declarative (I need this by three o'clock this afternoon). The effect of indirectness is to decrease the risk and soften the threat by lowering obligation and providing more options to continue the conversation. However, in the Indonesian culture, culture the use of a declarative sentence, as in 'I need this by three o'clock this afternoon', 
does not mean less polite in a particular circumstances. For example, if this statement is spoken by addressee's boss. In this case, the speaker has power to say this to his/her employee, and this is the employee's job to do what his/her boss wants. Another example is the conversation between a seller and a buyer. The buyer often says 'I want to buy a kilo of meat' instead of 'can I get a kilo of meat please'. In this case, we can use declarative sentence since we are the one who pays the seller, so we have power to do this. There is an assumption in the Indonesian culture that a buyer is exemplified as a "king" and the seller has to please them as a part of service. I notice that Australians do not use declarative sentence when buying something. They will say 'can I get a kilo of meat' instead of 'I want to buy a kilo of meat'. This difference may lead to misunderstanding if a non-native English speaker does not know the culture of the target language. To provide another example, the way Indonesians and Australians express apology has been clearly significant in various situation. For example, expressing apology or saying 'sorry' is often related to confession of mistakes and/ or asking for forgiveness in a very serious context where it needs to be done in a private manner like two persons talking together. However, this is definitely different when I noticed how Australians are so easily saying 'I am sorry' to other people even though they did not make the mistake. For example, when I was standing on the bus with some Australians and our bags bumped to each other incidentally, they directly said 'sorry' as soon as possible. At the first time, I always thought that it was totally fine and nothing serious happened there. Sooner, I asked myself why they said sorry all the time so easily. Then, I realized that Australia tended to say 'sorry' to reduce tension as soon as possible, especially for strangers.

Coulmas (2013) statement that indirectness strategy is used to minimize the acts, which can threaten the addressee's face and reduce the speaker's face at risk seems true. In Javanese culture, it is very sensitive to give orders or advice, to show one's dislike of the addressee, to express criticism and show disagreement. These acts are even more sensitive if they are done by younger people toward elders. According to Javanese cultural norm, younger people are not expected to give orders, advice and express criticism. If, however, they have to give advice, they have to express it in a very polite way by using indirect language. The speakers cannot express explicitly what they want or what they feel, but they are expected to say something else in such a way that the addressee can 
understand what the speakers really want him to do (Smith-Hefner, 1989). This strategy has also been proposed by Brown and Levinson (1987) in their offrecord strategy. They also listed some strategies that are probably related to Javanese's culture, such as giving hints, giving association clues, presupposing, understating or saying less than is required, overstating or giving information more than what is needed, using tautologies (uttering patent and necessary truth), using contradictions, being ironic, using metaphor, using rhetorical questions that do not require any answer, being ambiguous, being vague, overgeneralizing and not naming the hearer or addressing him directly, displacing, being incomplete by using ellipsis.

\section{CONCLUSION AND SUGGESTION}

To sum up, it seems to be clear that as each culture has their own values that may differ one from the others, politeness strategies are one of important subjects in language teaching and learning. The objective is not limited to only understand others' culture, but also understand why we are different, how we should react to the difference, how we should be proud of our own values, and how we should respect to the differences. What is highly valued in one culture may not be appreciated in another culture and some politeness strategies may not be easy to be accepted. Some people may think that, perhaps, it would be easy the speaker and the addressee are from the same culture. However, not even a society, each person itself may have different cultures depending on how their view is shaped in their community.

With all the differences, it should be clear that reaching one agreement in the society is the only way that humans beings should do to maintain harmony. Using appropriate linguistic choices in one culture, for example, would be one way to show appropriate politeness strategies. To do so, in the context of teaching and learning of target culture, language teachers, therefore, have responsibility to accommodate the concept of politeness strategies. In the future, it is expected that students could minimize misunderstanding in communicating to people from other cultures.

\section{REFERENCES}

Brown, P. \& Levinson, C. S. (1987). Politeness: some universals of language usage. Cambridge: Cambridge University Press.

Chojimah, N. (2015). Refusal and politeness strategies in relation to social status: A case of face- 
threatening act among Indonesian university students. Theory and Practice in Language Studies, 5(5), 906-918.

Coulmas, F. (2013). Sociolinguistic: The study of speakers' choices. Cambridge: Cambridge University Press.

Foley, W. (1997). Anthropological linguistics: An introduction.

Oxford: Basil Blackwell.

Fraser, B. (1983). The Domain of Pragmatics, In J. Richards and R. Schmidt (Eds.), Language and Communication (pp. 29-59). New York: Longman.

Kedveš, A. (2013). Face Threatening Acts and Politeness Strategies in Summer School Applications Calls. Jezikoslovlje, 14(2), 431-444.

Kramsch, C. (1998). Language and culture. Oxford: Oxford University Press.
Leech, G. N. (1983). Principles of pragmatics. England: Longman Group Limited.

Meier, A. J. (1995). Passages of politeness. Journal of Pragmatics, 24(4), 381-392.

Rinnert, C., \& Kobayashi, H. (1999). Requestive hints in Japanese and English. Journal of Pragmatics, 31(9), 1173-1201.

Smith-Hefner, J. N. (1989). A social history of language change in highland East Java. Journal of Asian Studies, 48(2), 256-273.

Spradley, J. P., \& McCurdy, D. W. (1980). Anthropology: The cultural perspective. John Wiley \& Sons.

Watt, J. R., Ide, S., \& Ehlich, K. (1992). Politeness in language: Studies in its history, theory and practice. New York: Mouton De Gruyter. 